総 説 (Review Article)：膜 (MEMBRANE), 20 (4), 246-254 (1995)

○特集：医療と膜

\title{
膜の医療への応用
}

宮嶋孝一郎

京都大学薬学部 昰 606 京都市左京区吉田下阿達町 46-29

\section{Application of membrane and film to medical and pharmaceutical fields}

\section{Koichiro Miyajima}

Faculty of Pharmaceutical Sciences, Kyoto University

46-29 Yoshida-shimoadachi-cho, Sakyo-ku, Kyoto-shi, 606 Japan.

Modified natural and synthetic polymers and phospholipids have been studied as membrane materials in medical and pharmaceutical fields. Chitin prepared from the carapace of carb and shrimp is biodegradable polymer of acetylglucosamine and easily forms a film and fiber from solution. The chitin film protects from an attack of bacteria, when covered on the wounded site and accelerates the recovery. Polymer membranes have been used as materials of microcapsules containing drugs inside, through oral, subcantaneous and intramuscular administrations. These microcapsules administred orally are capable to release drugs at tageting organ in time-dependent manner. Biodegradable polymer microcapsule implanted in muscle through injection, releases drugs for over 4 weeks at a constant rate.

Biodegradable and biocompatible phospholipids has been applied for the preparations of intraveneous administrations as a liposome and a microsphere. Liposomes and microspheres accumlate generally in reticuloendotherial system (RES). Recently RES-avoiding liposome has been developed by the modification of liposomal surface with polyethylene glycol and applied for an artificial red blood cell with undated hemoglobin. Lipid microsphere containing prostaglandin $\mathrm{E}_{1}$ and anti-inflammation drug had been applied for the cure of inflammation deseases, because the inflammation sites are macropharge-rich.

Key words : Polymer, phospholipid, Drug Carrier, Controlled release.

\section{緒 言}

膜の特性として隔離作用, 透過（圧力下では濾 過）による分離, 配向性をもつ反応場の提供など
が考えられる. 一方膜素材としては天然高分子, 合成高分子, 半合成高分子（フィルム）と, 生体 成分であるリン脂質や中性脂質よりなるリポソー ム（脂質 2 分子膜）や, エマルション（脂質単分 
子膜)の二種に大別される. 高分子よりなる膜は, リン脂質膜にくらべて膜厚が大きく種々の大きさ の細孔をもつ. また生体適合性, 生分解性はリン 脂質にくらべて劣り，血管系への投与剂型として 用いにくい. これに反してリン脂質よりなる膜は 膜厚も小さく, 生体適合性, 生分解性にもすぐれ, 血管内投与の可能な唯一の膜素材と考えられる.

医薬品素材としてこれらの膜を生体に応用する 場合, 基本的に毒性のないことが要求されるが, 目的とする臓器や組織に応じて, 素材は異なった ものになる.血管系(動脈, 静脈) に用いる場合, 生分解性の他に, 剂型が粒子の場合, 赤血球のよ うに変形しないために, 粒子の直径は $0.2 \mu \mathrm{m}$ 以 下が要求される. 一方経口投与製剤の場合, 高分 子, リン脂質いずれの素材も用いることができる が, 膜の強度や, 安定性から高分子膜が用いられ ている，筋肉や皮下に埋め込む剤型 (Implantion) では高分子膜素材の場合, 生体内での分解, 吸収されるものが要求される. 外用 (皮膚) 剂の 場合, 生分解性のある高分子が利用されている. 本稿ではシンポジウムで発表された報告を中心に 膜の性質を利用した薬物の送達について述べる.

\section{1. 外用製剂}

血液透析に高分子膜が実用に供されるように なって久しい. 純合成膜も用いられているが, セ ルロースを銅一アンモニア液で可溶化した再生セ ルロースの表面を, アミノ基やアンモニウム基で 修飾したものを中空糸膜に加工したもので，膜の もつ透過と滤過作用を利用して血中の老廃物（低 および中程度の分子, 分子量500～5,000）を除去 する. この膜は血液と直接接触するから, 有形成 分や血漿タンパク, 補体系成分などとの相互作用 のないものを用いなければならない1，血液透析 用中空系膜については, 昨年のシンポジウムの主 題の 1 つであり本稿ではのべない.

キチンは蟹や海老の甲らの主成分であり, $\mathrm{Ta}^{-}$ ble 1 に見られるようにセルロースの 2 位の水酸 基がアセチルアミノ基に置換されたもので,さら に脱アセチル化されたものがキトサンである，哺
乳動物に含まれる多糖は酸性ムコ多糖で, 負の荷 電をもっており，キトサンとは逆である．キチン を溶媒にとかし，展開したり紡糸すれば膜や繊維 に加工することができる，原料となるキチンは 100\%アセチル化体ではなく, 一部遊離のアミノ 基を含んでおり, 生体細胞が一般に負に荷電して いることから, 接着性のよさは静電相互作用も関 与しているかもしれない。この膜はリゾチームや N-アセチルグリコサミダーゼによって分解をう け，アセチルグルコサミンになり解糖系へと運ば れていく．これら生体に含まれる酵素系によって 分解されるために吸収されやすく, 投与部位から 消失しやすい. 直径 $10 \mu \mathrm{m}$ の微細繊維を厚さ $0.12 \mathrm{~mm}$ の不織布にしたものは, 通気性もよく 損傷を受けた皮膚の保護および修復剤として実用 化されている2). キチンを細孔形成剂で処理した キチンスポンジは, 人工粘膜, 人工軟骨として利 用されており, 医薬品領域では徐放性マイクロカ プセルの素材としても研究が行われている ${ }^{3)}$.

\section{2. 経口投与型マイクロカプセル}

従来酸性下（胃）で安定でアルカリ性下（腸） で溶解する腸溶錠 (Enteric coating Tablet) が, 膜素材としてセルロース醋酸・フタル酸エステル を用いて作られてきた. 最近高分子膜を用いる放 出制御型 (Time-controlled releasesy stem) マ イクロカプセルの開発が行なわれ始めた. 経口投 与形マイクロカプセル皮膜用高分子としては，工 チルセルロースやアンモニウム基をもつ Eudragit SR が用いられている (Table 1).これら 2 種の高分子は生分解生をもたないために, カプセ ルに内封された薬物の放出は膜透過性の变化や, 膜破壊によって起こる.これらカプセルの製造は 流動層造粒法によって薬物などをコートし，つい でスプレートドライ法によって皮膜を形成させる ものである. 膜透過性の変化, 膜破壊のいずれの 場合も, まず膜の細孔を通ってカプセル内に水が 浸入することが第一段階である.

エチルセルロースを皮膜とするマイクロカプセ ルである TES (Time-controlled Explosion 
Table 1. Chemical Structures and Conpositions of Membrane Materials.

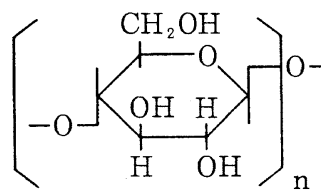

Cellulose

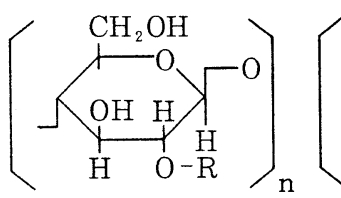
$\mathrm{R}: \mathrm{H},-\mathrm{C}_{2} \mathrm{H}_{5}-\mathrm{N} \backslash \mathrm{C}_{2} \mathrm{H}_{5}$

再生修飾セルロース (Regenerated modified cellulose)

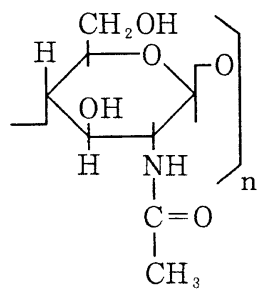

Chitin

$(1,4-\beta-)$<smiles>CCC(C)C(O)C(C)C(N)C(C)O</smiles>

Chitosan

置換度 $0.35 \sim 0.7$

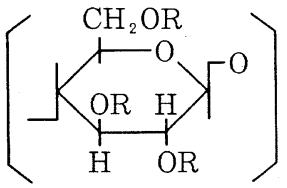

$\mathrm{R}:-\mathrm{H},-\mathrm{C}_{2} \mathrm{H}_{5}$<smiles>CCC(C)CO</smiles>

Ethyl, Hydroxypropyl cellulose<smiles>CCCCC(CC)(CC)C(CC)(CC)CC</smiles><smiles>CCC(C)(C(=O)OC)C(CC)(CC)C(C)(C)C(=O)OC</smiles>

Eudragit SR<smiles>CCCCCCCCC(=O)C(C)[N+](C)(C)C</smiles>
$\mathrm{n}_{1}: \mathrm{n}_{2}: \mathrm{n}_{3}$ $=1: 2: 0.1$ mw 150,000<smiles>CCC(C)OC(C)C(=O)C(CC)(CC)C(CC)(CC)OCC(=O)C(O)(CO)C(C)CC</smiles>

マイクロ 大豆油 $(100 \mathrm{mg})$, 卵黄レシチン $(12 \mathrm{mmg})$, クリセロール $(22.1 \mathrm{mg})$, オレイン酸 $(2.4 \mathrm{mmg})$,

スフェア $\mathrm{PGE}_{1}(2.4 \mathrm{ng})$, 粒径 $0.05 \sim 0.2 \mu \mathrm{m}$, マイクロスフェアーの膜組成 の組成

NRC の HPC : Chol : Mystinic Acid : $\mathrm{V}_{E}=7: 7: 2: 0.28,+\mathrm{PEGPE}$, 粒径 $0.2 \mu \mathrm{m}$ 膜組成

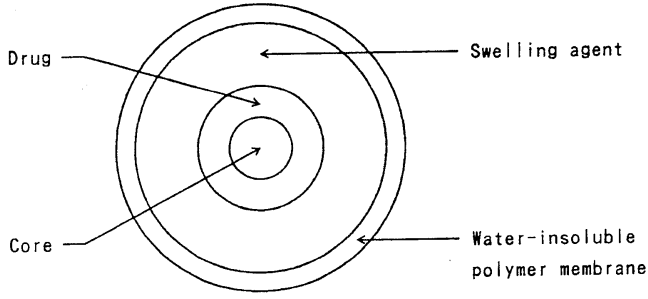

Fig. 1. Schematic cross-sectional view of Time-Controlled Explosion System (TES).
System) についてのべよう ${ }^{4)}$.Fig. 1 に見られ るように, TES は中心に芯物質, ついで薬物層, 水に不溶で膨潤性高分であるヒドロキシプロピル セルロース層があり，その外側をエチルセルロー ス膜で皮覆したものである. 薬物の放出機構とし ては, (1) 外部から高分子皮膜を介しての水の浸 入，(2) 浸入した水を膨潤剤が吸収し，水和によ る膨潤圧の発生，(3) 膨潤力による高分子皮膜の 破壊, (4) 薬物の外部環境への放出といった過程 
Table 2. Formulation of five types of TES containing Metoprolol ${ }^{a)}$.

\begin{tabular}{|c|c|c|c|c|c|c|}
\hline Function & Component & TES 0 & TES 1 & TES 2 & TES 3 & TES 4 \\
\hline Drug & Metoprolol tartrate & 10.0 & 10.0 & 10.0 & 10.0 & 10.0 \\
\hline Core & Sucrose beads ${ }^{b)}$ & 24.0 & 24.0 & 24.0 & 24.0 & 24.0 \\
\hline Swelling agent & $\mathrm{L}-\mathrm{HPC}^{c)}$ & 54.4 & 54.4 & 54.4 & 54.4 & 54.4 \\
\hline Binder & $\mathrm{HPMC}^{d)}$ & 11.6 & 11.6 & 11.6 & 11.6 & 11.6 \\
\hline \multirow{2}{*}{ Membrane } & Ethylcellulose $^{e)}$ & - & 10.0 & 15.0 & 20.0 & 33.0 \\
\hline & Talc & - & 2.0 & 3.0 & 4.0 & 6.6 \\
\hline
\end{tabular}

a) Each value is represented as weight ratio.

b) Nonpareil ${ }^{\circledR}$ seeds (350 $500 \mu \mathrm{m}$ in a diameter).

c) low-substituted hydroxypropylcellulose.

d) Hydroxypropylmethylcellulose ( TC-5R $\left.{ }^{\circledR}\right)$.

e) Grade : Ethocel $10 \mathrm{cps}$.

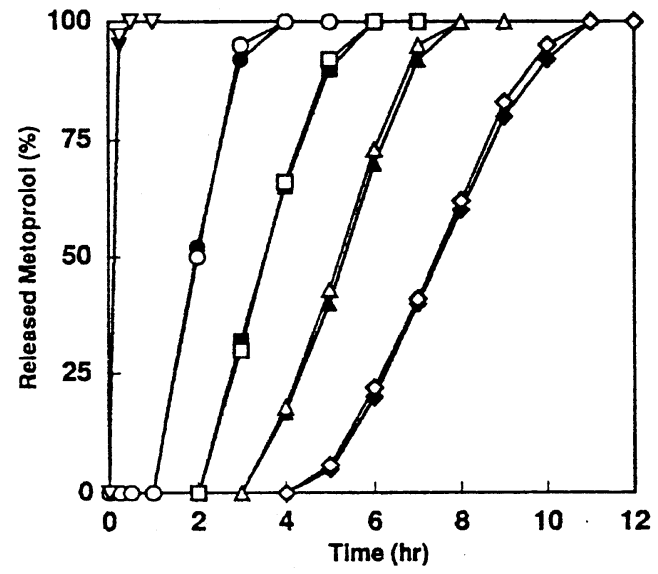

Fig. 2. Release patterns of metoprolol from TES in JP XII 1 st fluid (open key) and 2 nd fluid (closed key) at $37^{\circ} \mathrm{C}$ $\operatorname{TES} 0(\nabla, \boldsymbol{\nabla}) ; \operatorname{TES} 1(\bigcirc, \boldsymbol{\bullet}) ; \operatorname{TES} 2$ $(\square, \boldsymbol{\square}) ; \operatorname{TES} 3(\triangle, \boldsymbol{\Delta}) ; \operatorname{TES} 4(\diamond$, -). Each point describes the mean value of triplicated tests.

が考えられる.

(1)（2）の過程に要する時間が，放出の遅れ (lag time) として放出の時間制御を司ることに なる. 皮膜の厚さを一定として, 膨潤層の厚さを 変えた時, 膨潤層の厚さが小さければ, 発生する 膨潤力は小さく, 膜破壊は起こらないし, 逆に厚 さが大きいと,早く皮膜の崩壊が起こる. Table 2 に見られるように, 膨潤層の厚さを一定にし皮膜 の厚さを変えた時, Fig. 2(in vitro), Fig. 3

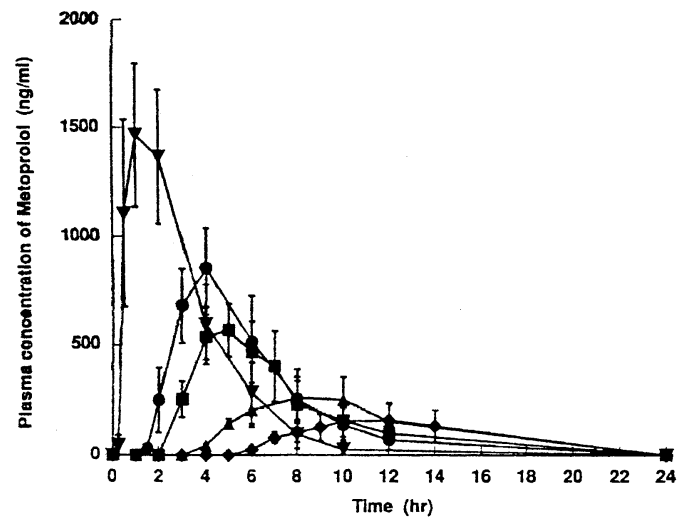

Fig. 3. Time-courses of mean plasma metoprolol concentration after oral administration of TES particles containing $120 \mathrm{mg}$ metoprolol tartarate to three fasted dogs

TES $0(\boldsymbol{\nabla})$; TES $1(\boldsymbol{\bullet})$; TES $2(\boldsymbol{\square})$; TES $3(\boldsymbol{\Delta})$; TES $4(\bullet)$. Each value is expressed as the mean $\pm \mathrm{S}$. D. of three animals.

(in vivo) に見られるように, 皮膜が厚くなれば 崩壊に要する時間 (lag time) は長くなる. 一般 に一定の lag time を経て, シグモイド型の溶出 一時間曲線を示すが, この lag time は次の実験 式で表わされることがわかった。

$$
\mathrm{T}_{\text {la }}(\mathrm{hr} .)=\frac{\mathrm{Q}_{D}{ }^{2}}{\mathrm{R}_{W}}=\frac{\left(\mathrm{k}_{2} \mathrm{~L}+\mathrm{Q}_{D O}\right)^{2}}{\left(\mathrm{k}_{1} / \mathrm{L}+\mathrm{R}_{W O}\right)}
$$

ここで $\mathrm{Q}_{D}$ は崩壊吸水量, $\mathrm{R}_{W}$ は吸水速度, $\mathrm{k}_{1}, \mathrm{k}_{2}$ 
はそれぞれ吸水速度定数, 崩壊吸水定数, L は膜 厚である。 $\mathrm{Q}_{D O}, \mathrm{R}_{W O}$ は $\mathrm{Q}_{D}-\mathrm{L}$ 曲線, $\mathrm{R}_{W}-1 / \mathrm{L}$ 曲 線における $\mathrm{L}, 1 / \mathrm{L}$ が零の点での $\mathrm{D}_{D}$ および $\mathrm{R}_{W}$ の值である，FK 409 と呼ばれ，血圧降下薬の ビーグル犬をつかったin vivo での血中濃度の推 移之，血圧の時間推移と連動していた。この方法 はカプセルの製法も簡単であり, 薬物の性質 (酸 性，塩基性，中性）によらずいずれの薬物にも適 用が可能で，その原理から考えても応用範囲が広 いと考えられる.

一方合成高分子である Eudragit を皮膜とする マイクロカプセルも放出時間制御機能をもち, SRS (Sigmoidal Release System) と命名され 研究が行われている ${ }^{5)}$. 皮膜の形成はスプレー コーティング法によっている. カプセルの基本構 造を Fig. 4 に示した. 今芯物のまわりに有機酸

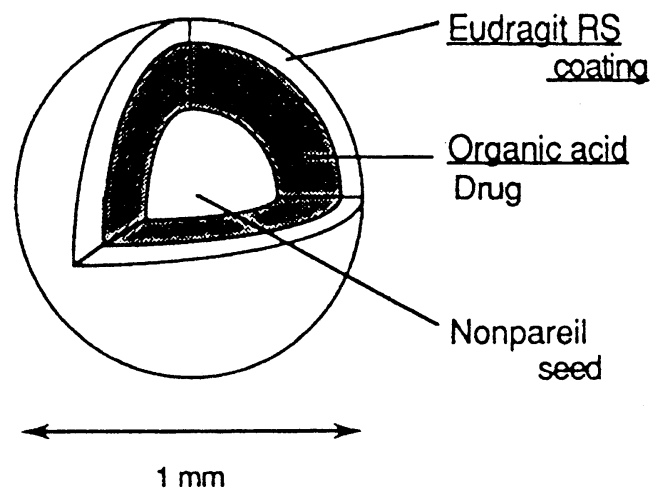

Fig. 4. Basic Structure of Sigmoidal Release System.
と薬物の混合物をコートし，これを皮膜で覆った マイクロカプセルである. 今このカプセルを水中 に入れると皮膜の細孔を通って水がカプセル内に 浸入し, カプセル内は水溶液状態になる.この時, イオン型の有機酸は Eudragit のアンモニウム基 と, 分子型のものは疎水性ドメインと相互作用し, 膜は膨潤し, 細孔は拡大する. 膜内外の浸透圧差 により, 内部の薬物の透過性は増大する. 放出機 構を Fig. 5 に示した. 酸の種類や皮膜形成物質 である Endragit に添加物を加えたり, 膜厚をか えることにより崩壊時間をかえることができる. Fig. 6 [A], [B] に膜厚をかえた時の in vivo, お よび，ビーグル犬を使った in vitro の血漿中濃 度の時間推移を示した. この方法は薬物の性質に よって適用ができないものがあると考えられる。 例えば酸性で分解するもの, 酸と反応して不溶性 の塩を形成するもの，また分子量の大きい夕ン白 質などである.

\section{3. 筋肉投与型微小マイクロカプセル}

ポリ乳酸／ポリグリコール酸の共重合体である 合成高分子は, 生分解性があり, 生体内でそれぞ れのモノマーに分解され組織に吸収される。この 高分子を塩化メチレンなどに溶かし, 薬物水溶液 $\left(\mathrm{W}_{1}\right)$ と混合して, まず $\mathrm{W}_{1} / \mathrm{O}$ 型のエマルション を作り，これに PVA 水溶液 $\left(\mathrm{W}_{1}\right)$ と混合して $\mathrm{W}_{1} / \mathrm{O} / \mathrm{W}_{2}$ 型三相エマルションを作る.この分散 液から溶媒を揮散させ, 内水相 $\left(\mathrm{W}_{1}\right)$ を保持した

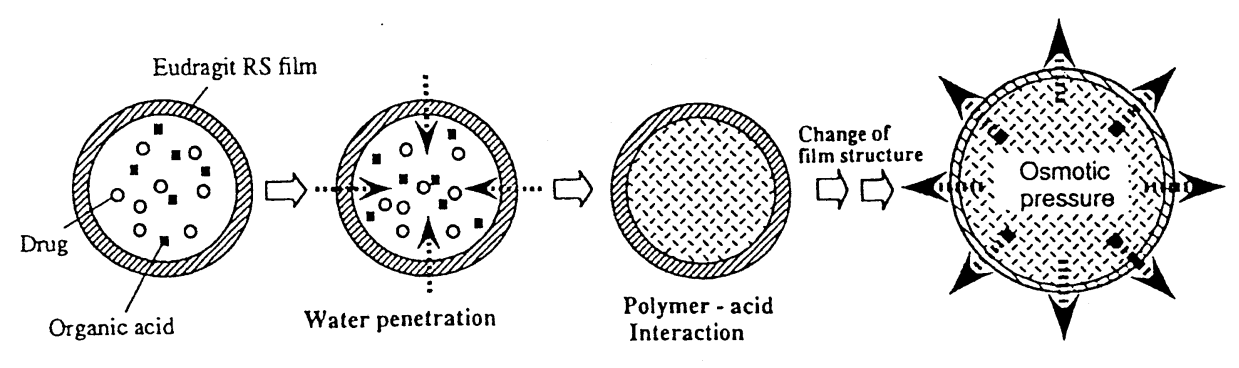

Lag time

Rapid release

Fig. 5. Possible drug release mechanism of SRS. 

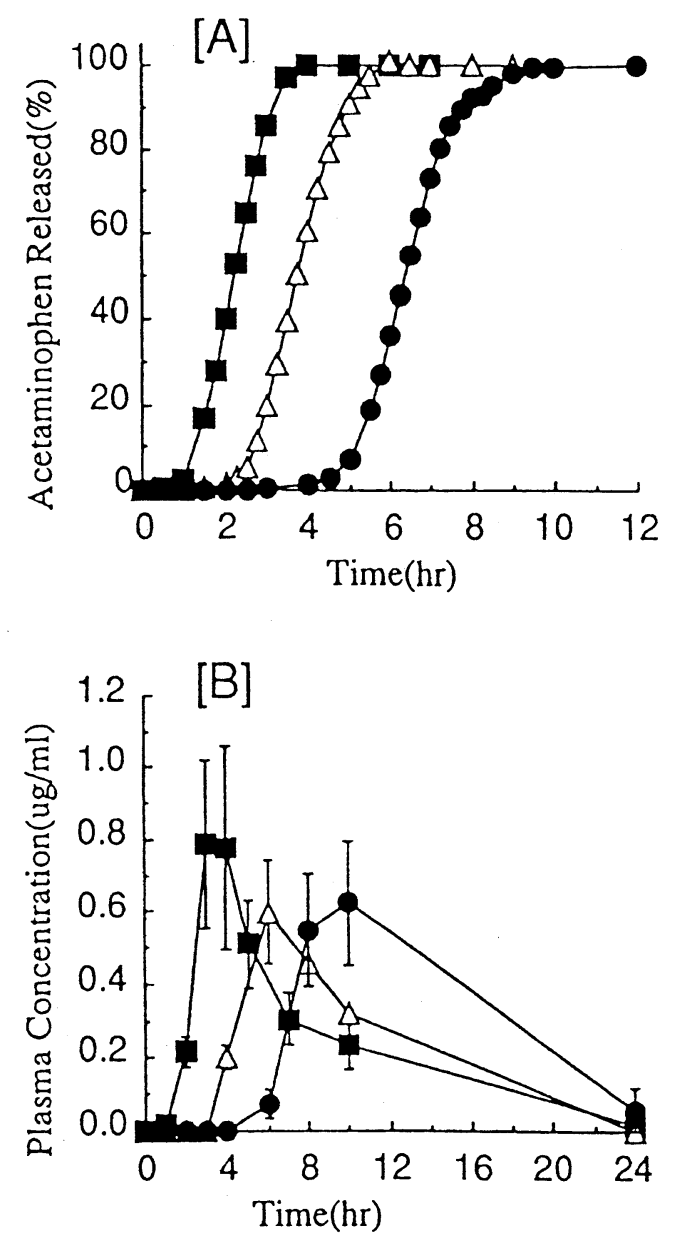

Fig. 6. In vitro drug release and in vivo performance of acetaminophen-SRS.

[A]: In vitro releases profile ; Lag time: $(\boldsymbol{\square}) ; 1.2 \mathrm{hr} ;(\triangle) ; 2.5 \mathrm{hr} ;(\mathbf{O})$; $5.0 \mathrm{hr}$. [B] : Plasma concentrationtime profile after oral administration to beagle dog ( $200 \mathrm{mg}$ dose, $\mathrm{n}=3$ ).

状態で固化させ，ついで凍乾により水分を除去， マイクロカプセルを得る. Fig. 7 にマイクロカプ セルを示した. SEM 写真によれば，粒経は 20〜 $30 \mu \mathrm{m}$ で微小な細孔をもっている. 薬物はマイク ロカプセル内にマトリックス状に存在する内水相 に保持されるが, この時, 塩基性薬物（リュウプ ロレリン ${ }^{6)}, \mathrm{TRH}$ (甲状腺ホルモン放出ホルモ

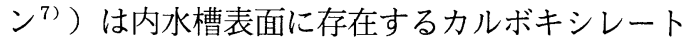

イオンと静電相互作用をもち強く保持される.こ の作用が薬物の徐放性に大きく寄与していると考 えられ，酸性および中性の薬物には適用できない のではないかと考えられる.この重合体の加水分 解はプロトンによって加速され，グリコール酸の 方が分解されやすい，薬物の放出機構としては水 のカプセル内浸入による膜構造の変化, 高分子の 加水分解および浸透圧差による膜破壊などが関与 していると考えられる (Fig. 8). リュウプロレリ ンではラットやイヌにおいて, 筋肉投与後 4 週間 にわたりほぼ一定の血液中濃度を維持することが 認められている. Fig. 9 に TRH 含有マイクロカ プセルの皮下注射後の血漿中濃度の時間推移を示 した.

\section{4. 脂質エマルション（マイクロスフェ アー）およびリポソーム}

血中に直接投与しうる膜素材としては, 生体膜 の主成分であるリン脂質が中心であり，その剂型 としては, 油溶性薬物については脂質エマルショ ンが用いられ, 水溶性薬物についてはリポソーム が用いられる. リポソームは脂質 2 分子層に油溶 性薬物も保持するため，いずれにも用いることも 可能である. 血中投与の場合，毛細血管を通過す るに充分な粒径 $0.2 \mu \mathrm{m}$ 以下が要求される. 大豆 油を油相とし, 膜素材としてレシチンを用いて得 られる脂質エマルションはリピドマイクロス ファーとも呼ばれ, 高カロリー輸夜として古くか ら繁用されている. また多くの脂溶性ビタミン (A， E， K ) も，HCO-60 などの非イオ型界面活 性剤が使用しにくくなった現在，この剂型にうっ りつつある．血管拡張作用や血漿板凝集作用をも つ $\mathrm{PGE}_{1}$ (プロスタングランディン $\mathrm{E}_{1}$ ) や，抗 炎症作用をもつデキサメタゾンの脂溶性プロド ラッグであるデキサメタゾンパルミテートの脂質 エマルションが作られ, 水溶性のリン酸デキサメ タゾンや, 水溶性シクロデキストリン包接体 $\left(\mathrm{CD}-\mathrm{PGE}_{1}\right)$ とその作用が比較された ${ }^{8)}$. Fig. 10 に見られるように CD-PGE $\mathrm{C}_{1}$ にくらべて，リ ピッドマイクロスファー $\mathrm{PGE}_{1}\left(\right.$ lipo $\left.\mathrm{EGE}_{1}\right)$ で 

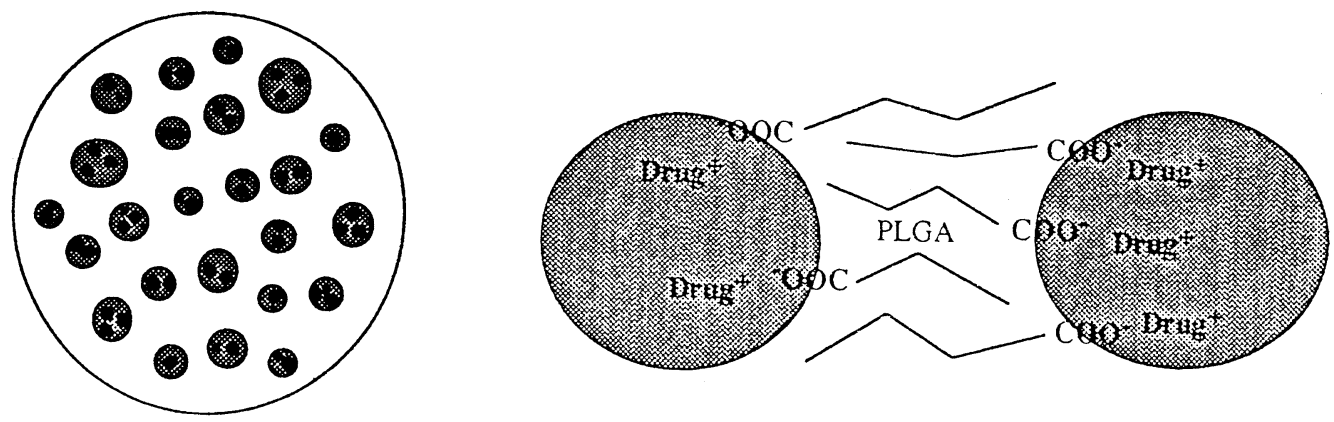

Fig. 7. Basic Structure of PLGA microsphere and the drug-PLGA interactions Hydrophilic end group of PLGA $\therefore$ Drug
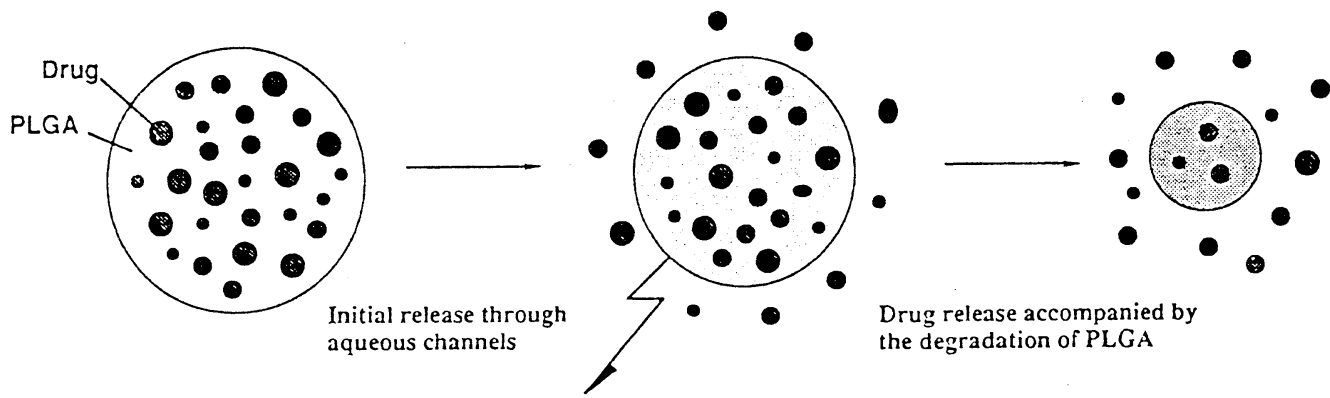

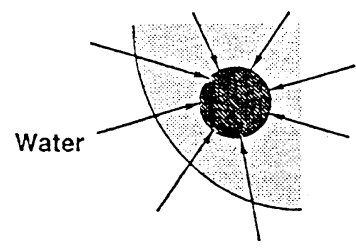

Pressure builds up inside the microspheres

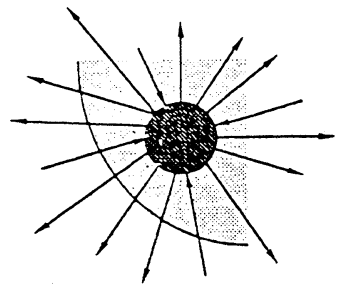

Polymer ruptures and the drug flows out

Fig. 8. Schematic representation of drug release mechanisms.

は，正常ラットで血圧降下作用が約 10 倍つよく， 糖尿病ラットではさらに顕著である. またデキサ メタゾンについても, リピッドマクイロスフェ アーは水溶性のものにくらべて $\mathrm{ED}_{50}$ で約 3 倍 効果が大きかった．この原因として，これらエマ ルションがマクロファージにとむ炎症部位や，血 管内皮細胞障害部位に選択的にとり込まれること が，電顕写真などから明らかにされている，一般 にリボソームは細網内皮系に取り込まれることに より，投与初期血流中より急速に消失し，二相性
の消失曲線を示す、リピドマイクロスフェアーで は LPL（リポプロテインリパーゼ）の作用によ り, 油相を形成するトリグリセライド（単分子膜 中の濃度は 3 モル \%）の分解が起こり，レシチ ン単分子膜は HDL（高密度リポタン白質）のプ レカーサーとなる，単位リン脂質量に対して大き い膜面積をもつ小さいエマルションの方が分解に よる消失速度が大きい. そのためにエマルション の消失を ${ }^{14} \mathrm{CTP}$ (トリパルミチン) をマーカー として求めると, スローフェーズの消失は小さい 


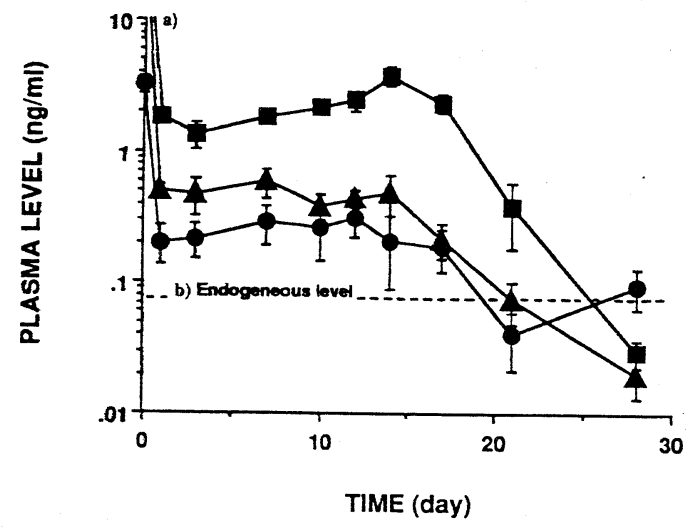

Fig. 9. Plasma TRH levels after s. c. injection of TRH/PLGA microspheres.

a) Plasma levels at $30 \mathrm{~min}: \boldsymbol{\Delta}, 35.9 \pm$

$2.27 \mathrm{ng} / \mathrm{ml} ; \mathbf{\square}, 85.8 \pm 8.14 \mathrm{ng} / \mathrm{ml}$

b) Mean plasma TRH level before administration of the microspheres.

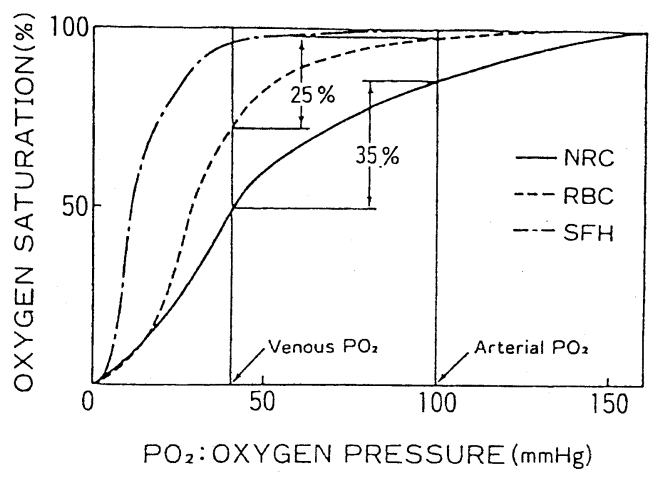

Fig. 11. Relation between Oxygen Saturation (\%) and Oxygen Pressure.

エマルションの方が大きい結果が得られている.

リポソームは脂溶性および両親媒性物質を 2 分 子膜層に, 水溶性物質を内水相に保持することが できる. $\mathrm{PGE}_{1}$ は有機カルボン酸であり, アルカ リ性では解離してカルボキシレートイオンにな る. 膜素材として水添レシチンを用い, 内水相を 重炭酸塩でアルカリ性とし, 外水相を弱酸性にし て，ここに $\mathrm{PGE}_{1}$ を加えるとリモートローディ ング法の原理にしたがって, 内水相に $\mathrm{PGE}_{1}$ を 濃厚な状態で封入することが出来る ${ }^{9)}$. 内水相に 移行した $\mathrm{PGE}_{1}$ はイオンの状態で存在し, 2 分子
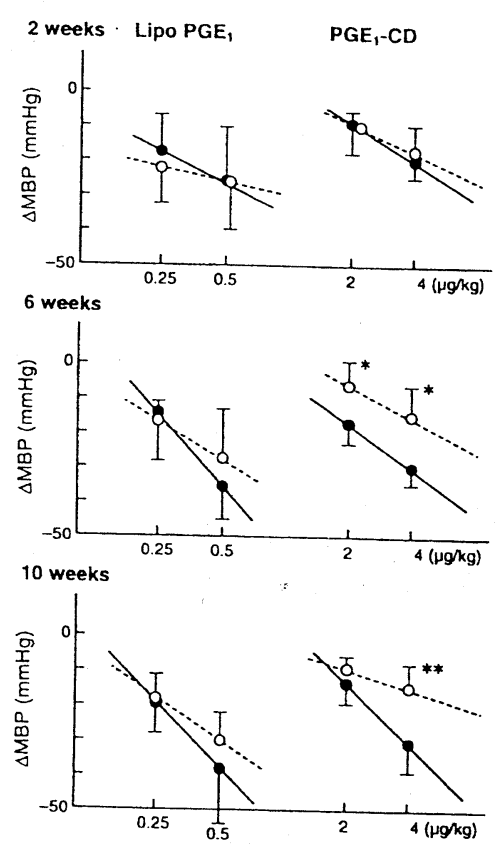

* $p<0.05$ compared with normal rats

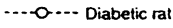

Fig. 10. Changes in mean blood pressure $\mathrm{MBP}$ ) in diabetic rats.

膜中では分子型で存在すると考えられる．このた めにリポソームに封入された $\mathrm{PGE}_{1}$ は $\mathrm{CD}-\mathrm{PGE}_{1}$ やlipo-PGE - $_{1}$ り血中からの消失速度が遅かっ た. ラットを用いた末梢血流増加作用は CD$\mathrm{PGE}_{1}$ にくらべて 3 倍増加し, 持続時間は 5 倍 に延長された。

ウイルス污染, 血液型, 保存性, 緊急時の利用 性などの理由から，血液の代りに人工的に作られ た代換血液の研究が古くから行なわれている. 代 換血液は通常赤血球の作用を代換するもので血液 全体ではない. 赤血球すなわち酸素運搬体として の作用である. しかしへモグロビン $(\mathrm{Hb})$ 単独で は血中からの消失速度も大きく, また酸素親和度 も大きく，さらにコロイド浸透圧も上昇し，実用 には供されない．その解決策として高分子修飾へ モグロビン (PEG 修飾), 重合へモグロビン, 架橋へモグロビンなどが研究されてきた。一方リ ポソームの研究の発展に伴って, 脂質小胞を利用 する研究もなされるようになってきた。 その $1 つ$ 
はリポソームの脂質 2 分子層に合成されたへムリ ピドを埋め込むもので，もう 1 つは $\mathrm{SFHb}$ （ス トローマフリーヘモグロビン）を脂質小胞の内水 相に封入するものである. リポソームに $\mathrm{SFHb}$ を封入した人工赤血球は浸透圧, 粘度共に低く, 内水相に酸素親和度を調節するピリドキサール 5 ’リン酸や，イノシトールリン酸を組み込こと によりすぐれた酸素運搬体となりうるが，へム鉄 が 2 価から 3 価に酸化されたメトへモグロビンは 酸素運搬能を失うため，これを還元する系を組み 込む必要があった. 鈴木等は上記化合物の他に赤 血球由来のメトへモグロビンリダクターゼと, そ の基質(アデニン,イノシトトール，グルコース） と補酵素 $(\mathrm{NADH}, \mathrm{NADPH})$ を加えて還元系を 形成させることにより，メトへモグロビン形成を 抑制することに成功した。一方りポソーム表面を PEG で修飾して親水化することにより, 細網内 皮系の捕捉から逃れ血流中での長時間安定化に成 功した(半減期 13 時間). 粒径もエクストルウダー 法により $0.2 \mu \mathrm{m}$ 以下に保つ之, 酸素濃度の高い ところでは Fig. 9 に見られるように赤血球にく らべて 1.5〜2 倍の酸素運搬能が得られている. このへモグロビン内封脂質小胞を NRC ( Neo Red Cell) と命名している. 出血性ショックによ る血圧低下からの回復も早く, SFHb に見られる 血圧上昇も一過性であった. NRC は低温保存に より 2 年間有効であるとされている. 以上最近の 膜の医薬への応用について述べたが, Bangham によって初めて多重リポソームが発見されて以来 30 有余年を経て, リポソーム製剤としてアンホ
テリシン B (商品名 : アンビソーム) 以外上市さ れていない事実は, 膜の生体への応用の困難さを 物語っているように思われる.

\section{文 献}

1）酒井清孝, 表面 31，(8) 600 (1993)

2）鶴谷良一, 技術談話会要旨集 P. 53 , 化学工学会東 海支部 (1993)

3）藤井尊ら“キチン・キトサンシンポジウム”講演 要旨集 P. 34 (1991)

4) S. Ueda, et al, Chem, Pharm Bull 42, 364 (1993) T. Hata et al, Intn, J. Pharm. 110, 1 7 (1994) S. Ueda et al, J. Drug Targeting 2, 133 (1994)

5) R. Ishino et al, Chem, Pharm Bull 40, 3036, 3094 (1992)

S. Narisawa et al, Pharm Res. 11, 111, (1994) 吉野広祐, 膜 19, 392 (1994)

6) Y. Ogawa et al, Chem. Pharm Bull. 36, 1095 (1988)

Y. Ogawa et al, J. Pharm, Pharmcol. 41, 439 (1989)

7) T. Heya, et al, Intn. J. Pharm. 69, 69, (1992)

T. Heya, et al, Intn. J. Pharm. 72, 199, (1992)

T. Heya, et al, J. Pharm. Sic. 83, 636, (1994)

T. Heya, et al, J. Pharm. Sic. 83, 798, (1994)

8）横山和正, 上田泰正, 油化学 43, 994 (1994)

9）上田泰正, 松田寛, 日本膜学会第 17 年会要旨集 P.27, 1995.

10）鈴木一比好, 後藤博, 上谷利治, 高橋晃, 人工血 液, 2, 391, 1993.

鈴木一比好, Bio Industry 9, 290 (1992)

薄場彰, 宮沢正紹, 鈴木一比好, 上谷利治, 人工 臟器, 22, 554 (1993)

（受付 1995 年 5 月 17 日） 